\title{
Use of Religious Doctrine and Symbolism in the IrAN-IRAQ WAR
}

\author{
Ardalan Rezamand, Simon Fraser University
}

\begin{abstract}
The political and economic isolation of the Islamic Republic, brought on by its ideological rejection of Western and Soviet influences, gave greater weight to the use of religion in a pragmatic, compensatory fashion. In particular, political leaders of Iran used Islamic doctrines, symbolism, and language to legitimize their wartime policy. In relying on religious justifications for the legitimacy of the war, Iran's political leaders had to conduct the war in a manner consistent with Islamic tenets, including their (Islamic tenets') reformulation to fit the demands of modern warfare. This paper elaborates on Iranian political leaders' use of Islamic juristic doctrines pertaining to offensive versus defensive jihad, war between Muslim states, and the Karbala paradigm as legitimizing agents during the course of the war. Furthermore, I argue that Iran's political leaders specifically reconstructed certain Islamic tenets, both via the ahadith and juristic precedence, in order to justify military actions such as retaliation against non-combatants, human wave attacks, and economic warfare.
\end{abstract}

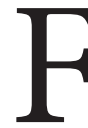
ollowing the 1979 Islamic Revolution, tensions mounted between Iran and Iraq over Iran's desire to export its revolutionary ideology beyond its borders and Iraq's claims to the eastern banks of the Arvand-Rud. The Iran-Iraq War erupted in September 1980 when the Iraqi forces initiated a full-scale invasion of Iran. The Iraqi government, observing the disorganization of 
the Iranian regime and military following the Islamic Revolution, rationalized the timing for such an assault as optimal. The Iran-Iraq War (1980-1988) negatively affected a large percent of the Iranian population and posed a great challenge to the new Islamic regime of Iran. During the nearly decade-long conflict, the political leaders of Iran employed religious doctrine and symbolism in order to increase popular support and participation in the war. Since the regime relied upon religious justifications to legitimize the conflict, the juristic interpretations they produced were ones clearly meant to ethically validate Iran's involvement in the war and the military tactics the regime employed in its wartime engagements. This essay analyzes the use of Islamic doctrine, symbolism, and language in the Iran-Iraq War by Iranian political leaders ${ }^{1}$ and argues that political necessity was the driving force behind the regime's reformulations of Islamic jurisprudence. In order for Islamic doctrines to be relevant vis-à-vis modern warfare, new juristic arguments had to emerge, and new fiqh (opinion of jurists) was applied to ensure that the Islamic Republic was engaging war in an Islamic way. While it is not possible to remark upon every instance of religious jurisprudential reformulation that occurred in relation to the Iran-Iraq war, this paper addresses key examples of doctrinal reinterpretations in order to give an analytical overview of how fiqh was reformulated to serve the Iranian regime's political interests.

\section{The Iran-Iraq War: A Brief Overview}

On September 22, 1980, the Iraqi armed forces initiated a full scale invasion of Iran, using infantry and mechanized divisions across a 730-mile front. Concurrently, the Iraqi air force attempted a decapitation strike against the Iranian air force-attacking over ten major airfields, including two in Tehran. ${ }^{2}$ The Iraqi government, realizing the disorganization of the Iranian government and military after the Islamic Revolution, thought the timing was optimal for a

1 By leaders, I am referring to key religious leaders such as Ayatollah Khomeini, Ayatollah Khamenei, Hojjat al-Islam Rafsanjani, and other clerical-political leaders of the Islamic Republic of Iran in the 1980s. Note that religious leaders, political leaders, and leaders of the Islamic Republic are referring to the same group and are used interchangeably for stylistic purposes throughout the article. 2 Sandra Mackey, The Iranians (New York, NY: Penguin Books, 1996), 318. 
military campaign. The Iranians put up a fierce defence and, in a matter of weeks, frustrated the Iraqi strategy for a short, conclusive war. In the proceeding months, Iran turned the tide of battle, reclaiming its occupied territories and eventually pushing the warfront into Iraq in April of 1982. Although the war continued for another six years, neither regime was capable of breaking the stalemate or forcing the other side to surrender. In 1984, the scope of the war broadened to include an unconventional warfare method, which directly targeted urban civilians in order to demoralize the domestic population of an enemy state. This method became known as War of the Cities. In 1986-87 the scope of the war once again increased with the Tanker Wars, the laying of mines in the Persian Gulf in order to disrupt shipping lanes. These disruptions negatively affected the regional and global economy and, as a result, the U.S. intervened directly in 1988 to protect shipping lanes in the Persian Gulf. The war ended a few months later with Iranian acceptance of U.N. resolution 598 followed by a protracted withdrawal of both sides to the 1975 Algiers border agreement.

Part I: Islamic Doctrine and Symbolism in Legitimization of the IranIraq War

In order to make up for a lack of organization and supply shortages during the conflict, the Iranian military sought to increase the number of soldiers providing frontline and logistical support to the war effort. However, Iranian political leaders understood that recruiting adequate human resources without incurring significant public backlash would be feasible only if there was high morale on the battlefield and at the home front. Thus, the leaders employed a number of religious doctrines, symbols, and rhetoric in an effort to create and control public support of the war. This section explores the use of Islamic jurisprudence and symbolism that had an impact on the legitimacy of the war, affecting mobilization, and morale.

Since the Islamic Republic of Iran portrayed itself as an Islamic state domestically and abroad, it had to legitimize its use of force with Islamic jurisprudence. Therefore, the state relied on Islamic precedents in the Qur'an, ahadiths ${ }^{3}$ and fiqh for the application and

3 Ahadith are considered to be the words and deeds of the Prophet. 


\section{Ardalan Rezamand}

construction of religious doctrines and symbolism during the war. The first stage of this religious authentication was to justify the war's legitimacy via the tenets of jihad. Jihad has many forms within Islam. It literally means the struggle in the way of God $(f i \text { sabil Allah })^{4}$ and is divided into the personal struggle to better oneself in the eyes of God (the lesser jihad) and the struggle to extend the word of God to all of mankind (the greater jihad). During the war, the Islamic Republic of Iran mobilized the concept of jihad primarily in the latter form. Jihad encompasses all conflicts between Muslims and non-Muslims, as well as conflicts between Muslims. Al-Mawardi (d. 1058) categorizes three types of jihad against believers: jihad against apostasy (al-ridda), jihad against dissension (al-baghi), and jihad against secession (almubaribun). ${ }^{5}$ Participation in jihad can be collective (fard kifaya) or individual (fard 'ayn) and may become a duty of every Muslim under certain conditions, i.e., defensive jihad. Thus, jihad is further divided into defensive and offensive types. This distinction is important especially in Shia sects because according to their traditions, only the Twelfth Imam can declare an offensive jihad; conversely, a defensive jihad can be declared by the head of the state. ${ }^{6}$

Since Iraq was seen as the clear aggressor of the war, ${ }^{7}$ Iran's religious leaders employed the concept of defensive jihad in order to legitimize their military response and mobilize the populace. Defensive jihad can be employed when the enemy has invaded Muslim territory ${ }^{8}$ or has "behaved in an unbearable manner." Repelling an enemy's attack is sanctioned by the Qur'an in surat al-baqara: "Fight in the way of Allah those who fight you, but do not provoke hostility; verily Allah

4 Mahmud Taleqani, "Jihad and Shahadat," in Jihad and Shahadat: Struggle and Martyrdom in Islam, ed. Mehdi Abedi and Gary Legenhausen (Houston, TX: The Institute for Research and Islamic Studies, 1986), 49.

5 Majid Khadduri, War and Peace in the Law of Islam (Richmond, VA: William Byrd Press, 1955), 74-76. Note that other variations of this concept exist which allow for the co-existence of Muslim and non-Muslim states under the tenets of Dar al-Ahd; however, for a religiously zealous government in its infancy (Iran in 1980s) the stricter definition is used here.

6 Haggay Ram, “Islamic 'Newspeak': Language and Change in Revolutionary Iran," Middle Eastern Studies 29, 2 (1993): 214; Khadduri, 94.

7 According to the United Nations, Iraq was considered to be the agressor.

8 John Kelsay, "Religion, Morality, and the Governance of War: The Case of Classical Islam," The Journal of Religious Ethics 18, 2 (1990): 126.

9 Ibid., 41. 
loveth not those who provoke hostility." ${ }^{10}$ Importantly, participation in a defensive jihad falls within the duties of the individual (fard 'ayn) and has fewer participatory constraints. ${ }^{11}$ For example, women and children are obligated to participate in a defensive jihad and children do not need parental permission before participation. In the case of the Iran-Iraq War, the battlefield was categorized as a collective jihad (fard kifaya) while the areas behind the front line were categorized as individual jihad (fard 'ayn). ${ }^{12}$ This meant that participation in military operations required parental permission while participation in support of the front, often referred to as the home front, did not require parental permission. Thus, minors could volunteer to move to forward positions and provide support by bringing water, food, and ammunition to the front line, increasing the scope of potential volunteers for the war effort.

This conventional understanding of defensive jihad sufficiently served its legitimacy purpose until April 1982, when Iraqi forces were expelled from Iranian territory. At this point a reformulation of the doctrine was required to legitimize the extension of the war into Iraqi territory; the religious legitimacy of the war had to rest on a concept of a defensive jihad, given the impossibility of legitimately waging an offensive jihad within the theological framework of Twelver Shi'a jurisprudence. This is because an opinion in Twelver Shi' ism states that, in the absence of Imam Mahdi, ${ }^{13}$ jihad enters a state of dormancy-no one has the right to declare an offensive jihad. ${ }^{14}$ This jurisprudential dilemma was resolved by an argument extending the defensive jihad doctrine to include offensive operations. Several members of Iran's religious leaders were employed in this effort: Ayatollah Khomeini, Ayatollah Mosavi Ardebili, and Ayatollah Ali Khamenei.

In a televised speech, Ayatollah Khomeini (d. 1989) stated, "this war was brought upon the people of Iran and now that the tides of

10 Saskia Gieling, Religion and War in Revolutionary Iran (London, U.K: I.B. Tauris \& Co., 1990), 41.

11 Kelsay, 126

12 Gieling, 46-47.

13 The Mahdi is the title of the twelfth Shicite imam who went into occultation and will return, according to Shía doctrine, to create a utopian Islamic government here on earth.

14 Khadduri, 67. 
battle have turned, Saddam Hussein proposes to make peace; it would be wrong for Iran to make peace with Iraq under the terms of a kafir (an infidel)."15 Also, Ayatollah Mosavi Ardebili (b. 1926) stated that "as long as Saddam attacks us from the rear line, we will also fight him ... Ali said: 'the aggressor should be destroyed on his own soil."'16 Ardebili was referring to Saddam's continued attacks on Iranian cities by missiles and aircraft, and the cutting off of Iranian access to the Tigris River. He drew parallels between the current war and Ali's war at the Battle of Siffin (657 A.D.), stating that "the Iranians should follow Ali's advice by drenching their swords in Saddam's blood as a response for his continued transgressions." ${ }^{\prime 17}$ This invocation of religious imagery was similar to Ayatollah Ali Khamenei (b. 1939) citing the Battle of Badr (624 A.D.) when the Muslims were not fighting a defensive war but waging an offensive war to extend the truth of God. ${ }^{18}$ This supposition, however, creates two problems. First, as previously mentioned, no Shiite jurist has the right to declare an offensive jihad. Second, war cannot be waged against another Muslim nation for the gain of territory and property.

The first problem was overcome by a slight reformulation of the principle of intezar. ${ }^{19}$ Normally, the Shica are in a state of passive intezar which advocates political quietism while awaiting the return of the Mahdi to declare the final jihad. Khomeini constructed the concept of active intezar in which the Muslim community actively induces the return of the Mahdi by striving to create ideal Islamic conditions on earth. In other words, by destroying Saddam's regime - a symbol of evil-the Iranians made the return of the Mahdi more probable. ${ }^{20}$ Thus, through the indoctrination of active intezar and the necessity to wage a defensive jihad into enemy territory based on Islamic precedents at the battles of Siffin and Badr, the religious leadership of Iran attained popular consent to continue the war. This

15 RuhallahKomeini, “Untitled," http://www.youtube.com/ watch?v=zPBYmoulxC4 accessed December 13, 2009.

16 Ram, 215. Speech delivered in August 1982.

17 Gieling, 113.

18 Ibid., 109.

19 Intezar is the process of waiting for the return of the Mahdi.

20 Gieling, 124. It should be noted that the concept of active intezar was first employed to mobilize the masses for the Islamic Revolution and later extended to the war. 
new legitimizing approach to the conflict was further cemented by the regime's elaborate distinction between harb (war) and jihad (struggle), a distinction that was used to overcome the second outstanding issue of offensive legitimization: waging war for material gains.

Harb is defined as a state of conflict between two states for the acquisition of territory and wealth. ${ }^{21}$ It is often associated with the wars fought during the eighth century Umayyad period in which the caliphs deviated from the sunnah (tradition) of the Prophet and waged war for material gain. ${ }^{22}$ Iran's religious leaders clearly did not want to be seen as waging a materially motivated war. Ayatollah Taheri (b. 1922) stated that Iran did not aspire to gain any Iraqi territory and that the object of the war was vanquishing of evil and freedom for the Iraqi people. ${ }^{23}$ This view was in line with Muslim legal theory that states the objective of war "is neither the achievement of victory nor the acquisition of the enemy's property; it is rather the fulfillment of a duty." ${ }^{24}$ Ayatollah Taleqani (d. 1979), a prominent figure in the Iranian Revolution and one whose ideology and fiqh enjoy popular support to this day, also differentiated between harb and jihad by stating that Islam values human life; during jihad people do not get "killed over emotionalism due to someone's agitation or to the 'isms' that they make today." ${ }^{25} \mathrm{He}$ was referring to the waging of war to ideological motivations such as those based in nationalism, patriotism, socialism, or capitalism. Interestingly, Taleqani fails to recognize the presence of emotions in the beliefs of Muslims waging jihad. Thus, by distinguishing the conflict as a jihad and not as harb, the political leaders of Iran carefully constructed their position to continue the war into Iraqi territory without declaring an offensive jihad or transforming the conflict into a regular war.

Besides legitimizing the war effort based on jihad's tenets, imagery of the Karbala paradigm was employed in establishing the understanding of the war as being a fight of good versus evil. For the Shi'a community, Imam Hussein's defiant stance at Karbala is

21 Ram, 211.

22 Khadduri, 71.

23 Ram, 213.

24 Khadduri, 102.

25 Taleqani, 64. 
the ultimate image of justice's sacrifice in the face of oppression. ${ }^{26}$ The religious leaders of the Islamic Republic employed Karbala's imagery-situating the war in the context of the greater struggle of justice against oppression-in order to mobilize the populace. ${ }^{27}$ The frontline was deemed a Karbala for the basiji (volunteer militia), ${ }^{28}$ and slogans and billboards stating that "every day is Ashura, every land is Karbala" ${ }^{29}$ were strategically employed by the regime to evoke feelings of religious obligation to participate in the war.

The ideological scope of the conflict was expanded when the Karbala paradigm was combined with the ideals of jihad in creating slogans, artwork, road signs, and billboards stating that "the road to Jerusalem passed through Karbala." ${ }^{30}$ Israel was seen as a source of oppression against Muslims. The liberation of Jerusalem and the Palestinians was used as another justification for continuing the war. This use of constructive imagery coincided with the Israeli invasion of Lebanon (June 1982). ${ }^{31}$

The Karbala paradigm is closely related to the concept of shahadat (martyrdom). Traditionally a shahid (martyr) was defined as someone who died for Hussein at Karbala; this concept was extended by Khomeini to someone who died in the revolutionary struggle, and later as someone who died in the war effort. ${ }^{32}$ Khomeini created the concept of active shahadat; meaning that it was no longer sufficient for the faithful to remember and mourn the death of Imam Hussein - the true believer was now required to emulate his seventy two companions at Karbala by seeking martyrdom in the war effort. ${ }^{33}$

26 Mateo Farzaneh, "Shi'i Ideology, Iranian Secular Nationalism and the IranIraq War (1980-1988)," Studies in Ethnicity and Nationalism 7, 1 (2007): 88-90.

27 Hamid Dabashi and Peter Chelkowski, Staging a Revolution: The Art of Persuasion in the Islamic Republic of Iran (London U.K.: Booth-Clibborn Co., 2000), 288.

28 Farzaneh, 95.

29 Ibid., 91.

30 Ram, 216.

31 Gary Sick, "Trial by Error: Reflections on the Iran-Iraq War," Middle East Journal 43, 2 (1989): 236.

32 Dabashi, 277.

33 Mehdi Abedi and Gary Lengenhausen, "Introduction," in Jihad and Shahadat: Struggle and Martyrdom in Islam, ed. Mehdi Abedi and Gary Legenhausen (Houston, TX: The Institute for Research and Islamic Studies, 1986), 26. 
In a televised speech, ${ }^{34}$ Khomeini asks Iranians and Palestinians why they would exhibit fear in the face of martyrdom or imprisonment: "You have to strive in the path of God to victory .... What are you afraid of? Martyrdom? Tell me what is so scary about martyrdom or imprisonment?" 35 Thus, as Geiling concludes, "the leaders sacralised the war by arguing that death for the cause of Islam was the noblest form of observance (of faith) anyone could attain," ${ }^{36}$ as well as "the surest way to paradise."37

The Karbala paradigm and its implications for martyrdom were then situated in the greater context of the fight between the just forces of the Islamic Republic and the oppressive, imperialist puppets of Saddam Hussein and his forces. ${ }^{38}$ Even greater, direct comparison of the Iran-Iraq War was made to the wars fought by the Prophet: "a newly established community under threat, facing the same problems as the community of the Prophet." ${ }^{39}$ This comparison was constructed in stages. First, the status of bughat (dissent) ${ }^{40}$ was applied to Saddam and the Bathist party. Bughat is one of three cases when a Muslim state can wage war against another. ${ }^{41}$ The same religious justification used by Imam Ali in his war against the Kharajites and during the fitna (revolt) was used to justify Shi'a Iran's war against Ba'thist Iraq. ${ }^{42}$

Khomeini stated that "we believe that this war is the first confrontation of truth and falsehood after one thousand and

34 Ruhallah Komeini, "Untitled," http://video.google.com/videosearch?hl=en\& $\mathrm{q}=$ Khomeini $\% 27 \mathrm{~s}+$ speeches\&sa $=\mathrm{N} \& \mathrm{tab}=\mathrm{sv} \# \mathrm{q}=$ Khomeini + speech \&hl=en\&vie $\mathrm{w}=2 \& \mathrm{emb}=0$ \&start $=30 \& \mathrm{qvid}=$ Khomeini + speech \&vid $=1330913934552547415$. Accessed December 13, 2009.

35 Ibid.

36 Gieling, 54 .

37 Ibid., 55.

38 Ruhallah Komeini, "Untitled."

39 Gieling, 107.

40 The careful reader will notice here that Saddam's regime is sometimes characterized as kufr, batel, and bughat, while the three have different meanings. This demonstrates the adaptability of religious terminology by Iran's religious leaders in progressing their various causes.

41 Gieling, 50. Al-Mawardi (d. 1058) categorizes three types of jihad against believers: jihad against apostasy (al-ridda), jihad against dissension (al-baghi), and jihad against secession (al-mubaribun) [cf. Majid Khadduri, War and Peace in the Law of Islam (Richmond, VA: William Byrd Press, 1955), 74-76.]

42 Ibid., 51. 
five hundred years ... in the age of Ali all the forces of kufr were summoned in order to launch a war against the Commander of the Faithful." ${ }^{43}$ Kufr was here used to describe Saddam and his regime, while the battle of haqq vs. batel (truth vs. falsehood) came to symbolize the Iranian government's struggle against its internal and external enemies. ${ }^{44}$ In illustrating this position, Khomeini cited a verse from the Qur'an, al-Anfal, which was revealed during the Battle of the Badr: "God wants to install truth in the world and remove falsehood." ${ }^{45}$ Khomeini also invited the military and people of Iraq to rise up against their imperialist puppet ruler, Saddam Hussein, who was waging war against true Islam: "I invite the Iraqi people to rise up against Saddam and select an Islamic leader from among them to rule Iraq according to Islamic tenets, and we (Iran) will support you in this endeavour." 46

The war also played a role in the formation of state-sponsored religious nationalism. While the Pahlavi regime had virtually eliminated all forms of religious symbolism in promoting its version of Iranian secular nationalism, the Islamic Revolution and the subsequent Iran-Iraq War witnessed the "amalgamation of secular and religious nationalism ... secular or modern nationalism was imbued with religious symbols playing a key role in the fight against Iraq." ${ }^{47}$ This process entailed two approaches. According to Farzaneh, "ethnosymbols," 48 such as the rowzeh sermons of Muhharam, and its taziyeh passion plays, were used to inspire religious nationalism, strengthening popular support for the war. As well, modern institutions such as universities, the home of modern nationalist thought, were equated with the war in the following manner: "our university is in the trenches: the entrance exam is the hejrat (the migration); the lesson is jihad (the struggle); and the diploma is shahadat (martyrdom)." ${ }^{49}$ The indoctrinating power of this message can be witnessed in the will of Azim Motuli Habibi, commander of a

43 Ram, 213.

44 Gieling, 82; cf. Khomeini, "Untitled," in which he calls the Iraqi regime a government of kufr and idolatry (Hookoomat-e Ishteraki).

45 Ibid.

46 Ibid.

47 Farzaneh, 87.

48 Ibid., 88.

49 Dabashi, 282. 
basij battalion: "I ask the youth and other brothers that if until now they have not succeeded in going to the front, this university for the development of humans, [to go] and to separate themselves from this world, a disloyal friend, to move in the direction of God." ${ }^{50}$

An important part in the process of cementing these ethnosymbolic concepts of nationalism was the employment of a certain type of language by the regime. Haggay Ram refers to this use of language as "newspeak." ${ }^{11}$ Newspeak is the method by which "the regime is seeking to enhance its legitimacy within Iran by employing certain Islamic terms in its political rhetoric." ${ }^{52}$ In addition to the already mentioned words such as jihad, Karbala, and shahid, Newspeak refers to culturally familiar terms and themes such as munafiq (hypocrite or doubter) to illicit the support of the populace. In this context the term munafiq applied to both internal and external enemies of the revolution: the Mujahedin and Saddam Hussein, respectively. ${ }^{53}$

Furthermore, the occasion of the war and the need to reformulate Islamic language ${ }^{54}$ to serve the regime's political aims served to radicalize the revolution. ${ }^{55}$ This radicalization meant that the war, along with the use of Islamic ideologies and symbolism, created a concomitant version of radical Islam, which would likely not have been possible in any other context. In other words, the necessities of war created religious constructions and reformulation of Islamic doctrines which served the political aspirations of radical Islamists within the regime. Their ascent to power owes as much to the war as it does to the revolution.

One of the by-products of this religio-nationalistic approach was the continued loyalty of the ethnic Arabs of Khozestan. One of Saddam Hussein's major blunders of the war was believing that the Arabs of Khozestan would defect to the Iraqi side after the invasion. This prediction proved false, with ethnic Arab militias putting up stiff

50 Farzaneh, 98-99.

51 Ram, 198.

52 Ibid., 199.

53 Ibid., 208-210.

54 By Islamic language, I am referring to words such as shahid, jihad, etc., which are both Arabic and have religious meaning.

55 Hossein S. Seifzadeh, "Revolution, Ideology, and the War," in Iranian Perspectives on the Iran-Iraq War, ed. Farhang Rajaee (Gainesville, FL: University Press of Florida, 1997), 91. 
resistance against Iraq while Iran's regular forces mobilized. Several factors contributed to the Arab minority's loyalty to Iran. First, the ethnic loyalties of Khozestanis were diluted by intermarriage with Persian $s^{56}$ given that Khozestan had been firmly under Iranian control since the time of the Qajars. ${ }^{57}$ Second, Iran's Arab citizens were Shi'a Muslims who did not wish to be ruled by a secular, Sunni regime. ${ }^{58}$ Third, the ethnic Arabs of Khozestan, along with the rest of Iran's Shi ite population, bought into the religious doctrines, symbolisms, and language used by the Iranian regime in securing popular support for the war. In short, the Khozestanis were no different from the Kurdish, Turkish, Mazandarni, or other ethnic Iranian minorities who answered the state's call to jihad.

Religious doctrines and symbols were also used to increase morale and raise volunteers for the war: "it was largely the clerics' sophisticated and efficient use of the people's religious sentimentsthe harnessing of the most evocative themes of Shi'ite Islam to their cause - that have kept alive the mass support and the revolutionaryreligious zeal of the Iranian people." ${ }^{\text {99 }}$ Indeed, Khomeini often stated that iman (faith) was a prerequisite for victory. ${ }^{60}$ This meant that morale was the paramount factor in determining Iran's ability to win the war, since without a high degree of morale, faith in victory becomes impossible. Khomeini's speeches in 1982, after the repulsion of Iraqi troops from Iranian territory, attest to the importance of iman in winning the war for Iran: "The Iranian nation had nothing but had faith. Faith made it victorious over all powers. The leaders of all other Muslim countries have everything but they do not have faith." 61

The use of imagery and symbolism also played an important role in increasing morale on the war front and across Iran. During the war, eighty-nine out of the ninety-five major military operations

56 Claudia Wright, "Religion and Strategy in the Iran-Iraq War," Third World Quarterly 7, 4 (1985): 846.

57 Nikki Keddie, "The Minorities Question in Iran," in The Iran-Iraq War: New Weapons, Old Conflicts, ed. Shirin Tahi-Kheli and Shaheen Ayubi (New York, NY: Praeger Publishers, 1983), 97.

58 Ibid., 97.

59 Ram, 216.

60 Gieling, 78.

61 Referring to Iraq and other Arab states that supported Iraq's war against Iran, i.e. Kuwait, Saudi Arabia; Dabashi, 278. 
undertaken by Iran had an Islamic name. ${ }^{62}$ In addition, almost every military unit was co-commanded by a military officer and a religious cleric. ${ }^{63}$ Thus, the troops were constantly reminded, with verbal imagery, ${ }^{64}$ of the necessity for sacrifice in a holy war. Along the front, large billboards containing Islamic verses and doctrines littered the scenery. As well, the uniforms and vehicles of the soldiers were decorated with various religious emblems. ${ }^{65}$ These forms of religious imagery were employed to strengthen the morale of the ground forces. Along the home front, religious imagery was employed through mediums such as television, radio, Friday sermons, murals, and posters to remind people of the necessity of their own sacrifices while strengthening the morale of the civilian population.

Maintaining the high morale of the forces and civilian population was crucial in the continuation of the war because "Iran fought the war with both hands tied; without dependable or rich allies, without access to weapons systems compatible with those in its inventory, and without the benefit of its own best-trained minds." ${ }^{\prime 66}$ The high-tech weapons systems purchased by the Shah in the 1970s were mostly useless during the conflict due to lack of supplies and training. According to analyst projections in 1976, Iran needed five to ten years of American support to be making efficient use of its high-tech weaponry. ${ }^{67}$ Accordingly the U.S. had the capability to immobilize major sections of the Iranian forces-most importantly the air forceby cutting off supplies, ${ }^{68}$ a situation which became a reality after the American Embassy hostage crisis.

Instead of interpreting this situation as a weakness, many religious leaders of the regime saw it as a source of strength akin to the early

62 Gieling, 126.

63 Dabashi, 282.

64 By verbal imagery, I'm referring to the visualization of certain Islamic tenets and history, such as the battle of Karbala. The image of Karbala was deeply ingrained in the minds of the soldiers to an extent that the mere utterance of the word invoked a mental image of the entire event.

65 Dabashi, 282.

66 Shahram Chubin, "The Last Phase of the Iran-Iraq War: From Stalemate to Ceasefire," Third World Quarterly 11, 2 (1989): 4.

67 MERIP Reports, "U.S. Arms Sales to Iran," Middle East Research and Information Project 51 (1976): 15-17.

68 Ibid. 
wars of Islam: "The strength of the Moslem Arabian army lay neither in the superiority of its arms nor in the excellence of its organizations, but in its higher morale, to which religion undoubtedly contributed its share." 69

The commander of the Revolutionary Guard, Mohsen Reza'i, was to say after the war: "They had armour and we did not. If our circumstances in the war are not taken into account when comparisons are made with classical warfare, it will be a major error on the part of the analysts. We were unarmed infantrymen against the enemy's cavalry. There are few instances in the history of Islam of such a war." ${ }^{70}$

Thus, by understanding the importance of morale in overcoming the organizational and technological weakness of Iranian armed forces, one can fully appreciate the success of Iran's religious leader's efforts in using religious doctrines, symbols, and language in the course of the nearly eight-year-long war. Equally significant was their use of Islamic doctrines and precedents in the actual conduct of the war. The use of religious ideology for justifying the war is only effective if military conduct is carried out along the same tenets. In short, if the Islamic regime wanted to appear ideologically consistent in its politics, it could only fight a religiously sanctioned war using religiously sanctioned methods.

Part II: Islamic Doctrine and Symbolism in the Conduct of the IranIraq War

Ending a few months before its eight-year anniversary, the IranIraq War was the longest inter-state war of the twentieth century. It was also a brutal war, with the frequent use of missiles and aircraft bombardments of urban centres, human wave assaults, and mine sweeper operations, as well as economic devastation resulting from the destruction of infrastructure and agricultural targets. Recognizing itself as an Islamic government, Iran had to wage war according to Islamic tenets, and for the most part its scale of brutality was

69 Khadduri, 92.

70 Chubin, 7. 
proportionally less than that of the Iraqi government. Iran attempted to cordon practice to precedent and, for the most part, it succeeded.

The use of modern weapons makes the employment of classical Islamic principles of warfare difficult. However, some parallels can be drawn by separating the weapons and strategies used from the intentions behind their application. The "war of cities", which saw the bombardment of Iranian and Iraqi cities during the course of the war, is a prime example. Iraq started the war of the cities in the Iran-Iraq conflict, and broadened its scope in 1984 and again in 1987-1988. ${ }^{71}$ The 1984 escalation was in retaliation for new Iranian offensives using massed infantry and was expanded to include chemical and naval warfare. ${ }^{72}$ The 1987-1988 escalation was part of Iraq's strategy in pressuring Iran to a ceasefire without compensatory demands. ${ }^{73}$ In the beginning, Iran was reluctant to retaliate against Iraqi cities. In a Friday sermon Akbar Hashemi Rafsanjani (b. 1934) stated,

[w]e do not take such evil measures. We are not allowed to attack areas which are inhabited by helpless women and children. This is not the way a Muslim soldier fights. O you wicked Saddams! It is clear that you never bothered to learn the history of the wars of Islam. Otherwise, you would have known that when the Prophet sent an army to war he did not allow his soldiers to cut trees, to persecute refugees, or to strike the injured. ${ }^{74}$

Instead of targeting Iraqi urban locations, the Iranians increased their own air defences and built underground shelters for their

71 Gieling, 23.

72 Sick, 236.

73 Chubin, 11.

74 Ram, 214. From a sermon delivered in September 1982. This view is not unchallenged; for example, Abu Yusuf (d. 798), in his Kitab Al-Kharaj, stated that "there is no objection to the use of any kind of arms against the polytheists, smothering and burning their homes, cutting down their trees and date groves, and using catapults." Abu Yusuf, "Kitab Al-Kharaj, The Legacy of Jihad: Islamic Holy War and the Fate of Non-Muslims, ed. Andrew G. Bostom (Amherst, NY: Prometheus Books, 2005), 179. Also, as will be shown in the essay, the necessities of war changed this position when Iran started to target Iraqi urban centres in July 1984. 
population. ${ }^{75}$ However, this approach was insufficient; civilian morale was being adversely affected within Iran while the regime was seen as unresponsive and weak, a fact that further emboldened the Iraqi military. Since no precedents for retaliation against the deliberate targeting of non-combatants existed in Islamic law, ${ }^{76}$ Iran had to reformulate rulings on the conduct of siege warfare for this purpose. The logic of this reformulation lays with the idea that while Iranian forces did not physically siege Iraqi cities, their bombardments from afar could bring about the surrender of the city amounting to a successful siege. Thus, the legality of urban bombardments lay with the permissibility of siege conduct and weapons based on Islamic precedents. One such precedent was during the Siege of Ta'if (630AD) when the Prophet stated that the killing of non-civilians would be permitted if the attack had to take place from a distance. ${ }^{77}$ The use of arrows, fire, flooding, and catapults had gained recognition in Islamic siege warfare. ${ }^{78}$ Their use was explained using Hanafi jurist Muhammad al-Shaybani’s (d. 805) interpretation of "just war":

If the Muslims stopped attacking the inhabitants of the territory of war for any of the reasons that you have stated, they would be unable to go to war at all, for there is no city in the territory of war in which there is no one at all of these you have mentioned. Necessity, the just war thinkers say, covers a multitude of sins in war. And yet, al-Shaybani does not appear to regard such acts as 'sinful.' It is difficult to be exacting here, due to the lack of evidence; but the implication is that the religious purpose of war, indeed the religious context in which the entire set of judgments about war takes place, has shaped the contours of war in such a way that a number of the substantive moral dimensions of just war thinking are altered, or drop out altogether. ${ }^{79}$

75 Chubin, 11.

76 Hamid Algar, "The Problem of Retaliation in Modern Warfare from the Point of View of Fiqh," in Iran-Iraq War: the Politics of Aggression, ed. Farhang Rajaee (Gainesville, FL: University of Florida Press, 1993), 194.

77 Ibid., 193.

78 Khadduri, 106.

79 Kelsay, 132. 
Thus, necessity governs the use of force against urban centres. ${ }^{80}$ While it is true that Iraqi cities were not directly besieged, they were nonetheless within the range of Iran's modern "arrows" (shells, bombs, and missiles) and justified by a religious precedent and the claim that use of these weapons would put a stop to a greater evil. Iran's targeting of Iraqi cities had certain limitations however. In order to avoid intentionally killing civilians, the Iranians often gave twentyfour hour notice to city residents of impending bombardments. ${ }^{81}$ This was especially true for cities like Basra that lay within artillery range of the Iranian forces. ${ }^{82}$ Notices were also dropped by plane or through radio broadcasts before missile strikes on Baghdad, which started in April of $1985 . .^{83}$ Iran also refrained from targeting shrine cities such as Karbala and Najaf. ${ }^{84}$ Prior warning and fewer city bombardments meant that Iraqi civilian casualties were four to eight times less than Iranian civilian casualties from Iraqi strikes. ${ }^{85}$

The destruction of life during the War of the Cities was accompanied by the destruction of property, broadly defined as economic warfare. Generally speaking, economic warfare is prohibited in Islam under Abu Bakr's (d. 634) doctrine of unnecessary destruction. ${ }^{86}$ This doctrine prohibits the unnecessary destruction of, among other things, people, animals, trees, and houses in the course of war. However, most Islamic jurists have altered and expanded these restrictions. For example, "Abu Hanifa laid down the rule that everything that the jihadists cannot bring under their control must be destroyed, including the houses, churches, trees, flocks and herds. Shaf ' $i$ contended that everything which is lifeless must be destroyed including trees." ${ }^{17}$ Furthermore, water canals can be destroyed, water

80 It is also worth mentioning that when Iran decided to attack Iraqi cities in 1984 , it had spent nearly all of the ammunitions left over from the Shah's regime; thus, its decision can also be regarded as an action to cover a greater weakness. Mackey, 324.

81 Abdel-Majid Trab Zemzemi, The Iran-Iraq War: Islam and Nationalisms (San Clemente, CA: United States Publishing Co., 1986), 183.

82 Chubin, 11.

83 Wright, 841.

84 Zemzemi, 184.

85 Ibid., 157.

86 Khadduri, 102.

87 Ibid., 103. 
supplies may be poisoned and fire can be used to make land unusable. ${ }^{88}$ The destruction of agriculture is also permitted if it contributes to the submission of the enemy forces, as was the case in the Siege of Ta'if:

The Prophet himself had the grapevines belonging to the inhabitants of Ta'if cut down ... he also had his men cut down the beautiful date plantations the Jewish tribe of the Banu-Nadir owned on the plain of Medina ....The Muslims themselves carried out these orders reluctantly; and so it became necessary for a verse from the Quran (59.5) to justify the Prophet's decision that he was obliged to take such a terrible course of action in order to subdue his adversaries. ${ }^{89}$

Iran's expansion of the war to include economic targets had some precedent based on the above examples. In addition, Khomeini and Grand Ayatollah Hussein-Ali Montazeri (b. 1922) added a new dimension to the concept of defensive jihad by including defence of national and economic interests..$^{90}$ Therefore, if the preservation of national and economic interests rested on the destruction of the enemy's economic targets then this activity was deemed legitimate under Islam. In other words, "Muslim combatants should aim exclusively at destroying the organized existence of $k u f r$, not eliminating indiscriminately all those under its sway." ${ }^{\prime 11}$ Since the elimination of organized kufr entails the removal of one's ability to commit kufr, then the means which allow it to commit kufr become valid under Islamic laws of war.

This new dimension of defensive jihad, as well as the softening of restrictions on economic warfare by Islamic jurists, allowed the Iranian forces to target Iraqi oil installations and agricultural fields. The Iranian military attacked Iraq by land, sea and air: the overland artillery was used to devastate nearby fields and economic targets, while aircrafts and naval ships were used to destroy targets deep inside Iraqi territory or in the Persian Gulf. There were no precedents

88 Ibid., 106.

89 Clement Huart, "The Law of War," in The Legacy of Jihad: Islamic Holy War and the Fate of Non-Muslims, ed. Andrew G. Bostom (Amherst, NY: Prometheus Books, 2005), 290.

90 Gieling, 45.

91 Algar, 192. 
for such air attacks, so they were categorized as being akin to distant attacks on enemy targets using projectiles, as addressed in classical Islamic rules of warfare, and were performed in accordance with the relevant Islamic laws. ${ }^{92}$ Unlike air attacks, Islamic precedents did exist for naval warfare, which was treated according to the rules governing siege warfare already discussed. ${ }^{93}$ The Iranian forces employed their navy in the first stages of the war but, after sustaining substantial losses, refrained from further deployments as the war progressed. ${ }^{94}$ Instead, the Iranian navy maintained a naval blockade, which was never broken during the war, against all Iraqi ships; ${ }^{95}$ given the high economic toll this had on Iraq, this blockade can be understood as a form of economic warfare. Also, Iran's threat to sink ships and close the Straits of Hormuz to all sea traffic falls within the new economic dimension of defensive jihad. In addition to the blockade and threats to shipping lanes, the primary target of Iran's economic warfare was Iraq's oil installation, which they sought to disable in an attempt to limit its capacity to wage war. ${ }^{96}$

There were other areas of combat in which the Iranian forces engaged under Islamic law. One was surprise engagements or night attacks. Traditionally, a call to battle accompanied by an invitation to Islam must be given before engaging the enemy. Therefore, the Jafari jurist Ash-shahid al-Awwal (d. 1385) places night attacks under the category of makruh. ${ }^{97}$ Other jurists such as Ibn Qudama (d. 1223) disagree, stating that "it is permitted to surprise the infidels under cover of night, to bombard them with mangonels .... The Prophet attacked the Banu Mustaliq unexpectedly, while their animals were

92 The logic here is that a weapon is the extension of a man's hand. The evolution of war has allowed weapons which figuratively extend a man's hand to strike at the enemy from afar, and can be crudely ordered in the use of hands, knives, swords, spears, arrows, bullets, shells, and missiles, with each weapon further extending the reach of a man's hand in war.

93 Khadduri, 113-114.

94 William O. Staudenmaier, "A Strategic Analysis," in The Iran-Iraq War: New Weapons, Old Conflicts, ed. Shirin Tahi-Kheli and Shaheen Ayubi (New York, NY: Praeger Publishers, 1983), 41.

95 Ibid., 41.

96 Bijan Mossavar-Rahmani, "Economic Implications for Iran and Iraq," 51-59.

97 Algar, 192. Makruh is the condition where some object or action is neither permitted (halal) nor forbidden (haram) under Sharia and is determined on a case by case basis. 


\section{Ardalan Rezamand}

still at the watering-place; he killed the men who had fought against him." ${ }^{98}$ The Islamic legitimacy of surprise night attacks is important since one of the most successful Iranian operations during the war was carried out in this manner. The Fao Peninsula was captured on February 11, 1986, by the Iranian forces under the cover of night and in a surprise attack. ${ }^{99}$ Its capture was significant since it cut off the Iraqis from the Persian Gulf.

A more questionable method of war was Iran's use of human wave assaults which incurred significant casualties. Iranian forces would often employ volunteers, some unarmed, against Iraqi fortified positions in the first stages of battle to wear down Iraqi resistance before the actual attack commenced. These human wave assaults included running over land mines to clear the way for tanks and armour. ${ }^{100}$ Lack of logistical and organizational support made such operations a necessity for Iranian forces during the war: "In 1984 Iraq could 'only' manage a 2.5 to 1 superiority in tanks, 4 to 1 in aircraft and APC and had 3 to 4 inferiority in artillery. This had widened by 1988 to 4 to 1 superiority in tanks, 10 to 1 in aircraft and 3 to 1 in artillery." ${ }^{101}$ An individual account of this behaviour and its popularity among Iranian forces can be seen in the will of Nasrullah Shahabi (d. 1982), written before undertaking a human wave assault operation:

I have preferred the martyr's way which is divine prosperity to the mundane hope ... Mother, I'm fighting with all my strength ... and now I am ready to sacrifice myself for my country ... Although you will cry because of my death, you will be majestic forever, and you will take pride in me because I have sacrificed myself for my country and you will say that he fought bravely and was proudly martyred. ${ }^{102}$

The use of human wave assaults in Islamic warfare is troubled by the interpretation that such attacks are suicidal; Islamic law strictly

98 Ibn Qudama, in The Legacy of Jihad: Islamic Holy War and the Fate of NonMuslims, ed. Andrew G. Bostom (Amherst, NY: Prometheus Books, 2005), 163, referring to a military operation in 627A.D.

99 Mackey, 327.

100 Ibid., 323.

101 Chubin, 4.

102 Farzaneh, 98. 
forbids suicide. Yet, martyrdom-celebrated as the ultimate act of religious sacrifice-is not forbidden (particularly in Shi'a sects). Therefore, the Iranian government justified the suicidal wave attacks as martyrdom. As discussed earlier, the Shi'a precedent for this act is Imam Hussein's defiant stance in Karbala. The use of religious imagery equating the front to Karbala psychologically heightened the sacrificial behaviour of Iranian soldiers in this regard. Similarly, the image of the Mahdi fighting in the trenches along with Iranian soldiers serves as another example to inspire martyrdom. Finally, some soldiers were literally given a key to heaven, which they wore around their necks before undertaking human wave attacks. ${ }^{103}$ But are there Islamic precedents of suicidal behaviour in battle besides Iranian Shi'a cases relating to the Iran-Iraq War or Karbala?

An authentic account informs us that a man from the Prophet's entourage asked him what pleased God the most on the part of His servants. 'That he should plunge into the enemy ranks without helmet or breastplate', the Messenger replied. Then the man took off his coat of mail and penetrated the enemy formations until he was killed. ${ }^{104}$

Another classical example is when al-Shaybani states that it is permissible for a wounded warrior to continue his attack even though his wounds worsen to the point of becoming fatal. ${ }^{105}$ More recently, Yusuf al-Qaradawi (b. 1926) praises martyrdom in the ArabIsraeli conflict by stating that it is permissible for a Muslim "to risk himself and even get killed" in the cause of God." ${ }^{106}$ He continues by distinguishing suicide in which a man "kills himself for himself" 107 from martyrdom in which a man "sacrifices himself for the sake of a higher goal (God's glory)." 108 These examples illustrate that, throughout

103 Mackey, 323.

104 Roger Arnaldez, in Bostom, 273.

105 Kelsay, 134.

106 Yusuf al-Qaradawi, "Untitled," in The Legacy of Jihad: Islamic Holy War and the Fate of Non-Muslims, ed. Andrew G. Bostom (Amherst, NY: Prometheus Books, 2005), 248.

107 Ibid., 249.

108 Ibid. 
the history of Islam, martyrdom in battle had religious justification, thus the Iranian forces could validate their military strategy as not simply permissible, but necessary, for the Muslim believer.

In conclusion, the political leaders of Iran employed a combination of religious doctrines, symbols, and language to justify the war effort and incite participation and high morale from the populace. This approach was based both on the Islamic ideology of Iran's government, especially in its juristic guise, as well as the practical necessity of overcoming Iran's inferior military organization and logistics. Juristic concepts-such as defensive jihad and the war of truth versus falsehood-and provocative imagery such as the Karbala paradigm were constructively reformulated to fit the demands of war. At the same time, conditions of modern warfare induced the reformulation and construction of Islamic laws of war for a modern application. In particular, the use of human wave assaults, bombardment of urban areas, and economic warfare, were justified using Islamic precedents centering on the necessities of overcoming a greater evil at the cost of committing a lesser one. In short, the Iranians chose to fight a religiously sanctioned war using religiously sanctioned methods and, for the most part, they succeeded.

\section{Bibliography}

Abedi, Mehdi, and Gary Lengenhausen. "Introduction." In Jihad and Shahadat: Struggle and Martyrdom in Islam, ed. Mehdi Abedi and Gary Legenhausen, 1-46. Houston, TX: The Institute for Research and Islamic Studies, 1986.

Abu Yusuf. "Kitab Al-Kharaj." In The Legacy of Jihad: Islamic Holy War and the Fate of Non-Muslims, ed. Andrew G. Bostom, 174181. Amherst, NY: Prometheus Books, 2005.

Algar, Hamid. "The Problem of Retaliation in Modern Warfare from the Point of View of Fiqh." In Iran-Iraq War: the Politics of Aggression, ed. Farhang Rajaee, 191-197. Gainesville, FL: University of Florida Press, 1993. 
Al-Qaradawi, Yusuf. "Untitled." In The Legacy of Jihad: Islamic Holy War and the Fate of Non-Muslims, ed. Andrew G. Bostom, 248250. Amherst, NY: Prometheus Books, 2005.

Arnaldez, Roger. "The Holy War According to Ibn Hazm of Cordova." In The Legacy of Jihad: Islamic Holy War and the Fate of Non-Muslims, ed. Andrew G. Bostom, 267-281. Amherst, NY: Prometheus Books, 2005.

Chubin, Shahram. "The Last Phase of the Iran-Iraq War: From Stalemate to Ceasefire." Third World Quarterly 11, 2 (1989): $1-14$.

Dabashi, Hamid, and Peter Chelkowski. Staging a Revolution: The Art of Persuasion in the Islamic Republic of Iran. London, U.K.: Booth-Clibborn Co., 2000.

Farzaneh, Mateo. "Shi'i Ideology, Iranian Secular Nationalism and the Iran-Iraq War (1980-1988)." Studies in Ethnicity and Nationalism 7, 1 (2007): 86-103.

Gieling, Saskia. Religion and War in Revolutionary Iran. London, U.K.: I.B. Tauris \& Co., 1990.

Huart, Clement. "The Law of War." In The Legacy of Jihad: Islamic Holy War and the Fate of Non-Muslims, ed. Andrew G. Bostom, 282-292. Amherst, NY: Prometheus Books, 2005.

Ibn Khaldun. "The Muqaddimah.” In The Legacy of Jihad: Islamic Holy War and the Fate of Non-Muslims, ed. Andrew G. Bostom, 161. Amherst, NY: Prometheus Books, 2005.

Ibn Qudama. "Legal War." In The Legacy of Jihad: Islamic Holy War and the Fate of Non-Muslims, ed. Andrew G. Bostom, 162--164. Amherst, NY: Prometheus Books, 2005.

Keddie, Nikki. “The Minorities Question in Iran.” In The Iran-Iraq War: New Weapons, Old Conflicts, ed. Shirin Tahi-Kheli and Shaheen Ayubi, 85-107. New York, NY: Praeger Publishers, 1983. 


\section{Ardalan Rezamand}

Kelsay, John. "Religion, Morality, and the Governance of War: The Case of Classical Islam." The Journal of Religious Ethics 18, 2 (1990): 123-139.

Khadduri, Majid. War and Peace in the Law of Islam. Richmond, VA: William Byrd Press, 1955.

Khomeini, Ruhallah. Untitled. http://www.youtube.com/ watch?v=zPBYmoulxC4; Internet; accessed December 13, 2009.

Khomeini, Ruhallah. Untitled. http://video.google.com/videosearch ?hl=en\&q=Khomeini\%27s+speeches\&sa $=\mathrm{N} \& \mathrm{tab}=\mathrm{sv} \# \mathrm{q}=\mathrm{Khom}$ eini + speech\&hl $=$ en \&view $=2 \&$ emb $=0 \&$ start $=30 \&$ qvid $=$ Khomei ni+speech\&vid $=1330913934552547415$, accessed December 13, 2009.

Khomeini, Ruhallah. Untitled. http://video.google.com/videosearch? $\mathrm{hl}=\mathrm{en} \& \mathrm{q}=$ Khomeini\%27s+speeches\&sa $=\mathrm{N} \& \mathrm{tab}=\mathrm{sv} \# \mathrm{q}=$ Khomei ni\%27s+iran+iraq+war\&hl=en\&emb $=0 \& v i e w=2 \& q v i d=$ Khome ini\%27s+iran+iraq+war\&vid=-3456487425929212111 accessed December 13, 2009.

Mackey, Sandra. The Iranians. New York, NY: Penguin Books, 1996.

MERIP Reports. "US Arms Sales to Iran." Middle East Research and Information Project 51 (1976): 15-18.

Mossavar-Rahmani, Bijan. "Economic Implications for Iran and Iraq." In The Iran-Iraq War: New Weapons, Old Conflicts, ed. Shirin Tahi-Kheli and Shaheen Ayubi, 51-64. New York, NY: Praeger Publishers, 1983.

Ram, Haggay. "Islamic 'Newspeak': Language and Change in Revolutionary Iran." Middle Eastern Studies 29, 2 (1993): 198219.

Seifzadeh, Hossein S. "Revolution, Ideology, and the War." In Iranian Perspectives on the Iran-Iraq War, ed. Farhang Rajaee, 90-97. Gainesville, FL: University Press of Florida, 1997. 
Shemirani, S. Taheri. "The War of the Cities." In Iran-Iraq War: the Politics of Aggression, ed. Arhang Rajaee, 32-40. Gainesville, FL: University of Florida Press, 1993.

Sick, Gary. "Trial by Error: Reflections on the Iran-Iraq War." Middle East Journal 43, 2 (1989):230-245.

Staudenmaier, William O. "A Strategic Analysis." In The Iran-Iraq War: New Weapons, Old Conflicts, ed. Shirin Tahi-Kheli and Shaheen Ayubi, 27-48. New York, NY: Praeger Publishers, 1983.

Taleqani, Mahmud. "Jihad and Shahadat." In Jihad and Shahadat: Struggle and Martyrdom in Islam, ed. Mehdi Abedi and Gary Legenhausen, 47-80. Houston, TX: The Institute for Research and Islamic Studies, 1986.

Wright, Claudia. "Religion and Strategy in the Iran-Iraq War." Third World Quarterly 7, 4 (1985): 839-852.

Zemzemi, Abdel-Majid Trab. The Iran-Iraq War: Islam and Nationalisms. San Clemente, CA: United States Publishing Co., 1986. 